\title{
Comparison of microsatellites and isozymes in genetic diversity studies of Oryza glumaepatula (Poaceae) populations
}

\author{
Marines M. G. Karasawa1 ${ }^{1}$, Roland Vencovsky², Cynthia M. Silva², Daruska C. Cardim³,
} Eduardo de A. Bressan ${ }^{4}$, Giancarlo C.X. Oliveira ${ }^{2}$ \& Elizabeth A. Veasey ${ }^{2}$

1. Departamento de Ciências Biológicas e da Terra, Universidade Federal de Alfenas (UNIFAL), 37300-000 Alfenas, Minas Gerais, Brazil; mgniechk@yahoo.com.br

2. Departamento de Genética, Escola Superior de Agricultura "Luiz de Queiroz", Universidade de São Paulo, ESALQ/ USP, Caixa Postal 83, 13400-970 Piracicaba, São Paulo, Brazil; rvencovs@esalq.usp.br, cynthia.esalq@gmail.com, eaveasey@esalq.usp.br, gcxolive@gmail.com

3. SEMASA-Serviço Municipal de Saneamento Ambiental de Santo André, R. José Caballero, 143, 09040-210 Santo André, São Paulo, Brazil; daruskacardim@yahoo.com.br

4. Centro de Energia Nuclear na Agricultura, CENA/USP, Piracicaba, SP, Brazil; ebressan@cena.usp.br

$$
\text { Received 03-XI-2011. Corrected 06-V-2012. Accepted 07-VI-2012. }
$$

\begin{abstract}
The study of the genetic structure of wild plant populations is essential for their management and conservation. Several DNA markers have been used in such studies, as well as isozyme markers. In order to provide a better comprehension of the results obtained and a comparison between markers which will help choose tools for future studies in natural populations of Oryza glumaepatula, a predominantly autogamous species, this study used both isozymes and microsatellites to assess the genetic diversity and genetic structure of 13 populations, pointing to similarities and divergences of each marker, and evaluating the relative importance of the results for studies of population genetics and conservation. A bulk sample for each population was obtained, by sampling two to three seeds of each plant, up to a set of 50 seeds. Amplified products of eight SSR loci were electrophoresed on non-denaturing polyacrylamide gels, and the fragments were visualized using silver staining procedure. Isozyme analyses were conducted in polyacrylamide gels, under a discontinuous system, using six enzymatic loci. SSR loci showed higher mean levels of genetic diversity $\left(A=2.83, p=0.71, A_{P}=3.17, H_{o}=0.081\right.$, $\left.H_{e}=0.351\right)$ than isozyme loci $\left(A=1.20, p=0.20, A_{P}=1.38, H_{o}=0.006, H_{e}=0.056\right)$. Interpopulation genetic differentiation detected by SSR loci $\left(R_{S T}=0.631\right.$, equivalent to $\left.F_{S T}=0.533\right)$ was lower than that obtained with isozymes $\left(F_{S T}=0.772\right)$. However, both markers showed high deviation from Hardy-Weinberg expectations $\left(F_{I S}=0.744\right.$ and 0.899 , respectively for SSR and isozymes). The mean apparent outcrossing rate for SSR $(\bar{t}=0.14)$ was higher than that obtained using isozymes $\left(\bar{t}_{a}=0.043\right)$, although both markers detected lower levels of outcrossing in Amazonia compared to the Pantanal. The migrant number estimation was also higher for SSR $(\mathrm{Nm}=0.219)$ than isozymes $(\mathrm{Nm}=0.074)$, although a small number for both markers was expected due to the mode of reproduction of this species, defined as mixed with predominance of self fertilization. No correlation was obtained between genetic and geographic distances with SSR, but a positive correlation was found between genetic and geographic distances with isozymes. We conclude that these markers are divergent in detecting genetic diversity parameters in O. glumaepatula and that microsatellites are powerful for detecting information at the intra-population level, while isozymes are more powerful for inter-population diversity, since clustering of populations agreed with the expectations based on the geographic distribution of the populations using this marker. Rev. Biol. Trop. 60 (4): 1463-1478. Epub 2012 December 01.
\end{abstract}

Key words: genetic structure, gene flow, isozymes, mating system, SSR.

Oryza glumaepatula Steud. (Poaceae) is one of the four wild rice species originated in America, the others being O. latifolia, O. grandiglumis and $O$. alta (Morishima 1994), and occurs widely in Latin America from $23^{\circ} \mathrm{N}$ in Cuba to $23^{\circ} \mathrm{S}$ in Brazil (Vaughan et al. 2003). It is the only diploid wild American species and its importance relies on its use in crosses with 
O. sativa in plant breeding programs (Brondani et al. 2001, Yoshimura et al. 2010) aiming at introgression of important traits from the wild species and amplifying the genetic basis of the cultivated crop.

The Brazilian O. glumaepatula populations are found in the extensive river basins of the Amazon and Pantanal Matogrossense and the smaller river basins which occur in the states of Goiás and Tocantins (Oliveira 1994, Brondani et al. 2005). This species presents annual, bi-annual or perennial populations, depending on its geographical location (Oliveira 1993, Akimoto et al. 1998), growing along the riverbeds and margins, presenting behavior typical of weeds or colonizing plants. As limited portions of their culms rot and their bodies are released to float on the surface, they are dispersed on the rivers by the force of wind and water, mostly downstream (Akimoto et al. 1998), but sometimes upstream (Black 1950), founding new populations or clustering to those already existing.

The Oryza genus presents different reproductive systems such as outcrossing, inbreeding, intermediate crossing rates and vegetative reproduction. Several studies have indicated that $O$. glumaepatula is a self-fertilizing species (Akimoto et al. 1998, Buso et al. 1998, Ge et al. 1999), but recently studies have reported that this species has different outcrossing rates in different populations, with values ranging from $9.3 \%$ to $30 \%$ (Brondani et al. 2005, Karasawa et al. 2007a,b, Vaz et al. 2009). The breeding system was classified as mixed with predominance of inbreeding by Karasawa et al. (2007b).

The knowledge of genetic diversity and genetic structure of populations is essential for understanding species evolution, the genetics of natural populations, as well as the adoption of collecting strategies aiming at in situ or ex situ management, restoration and conservation practices (Slatkin 1987, Vigouroux et al. 2008). Several molecular techniques are available for the detection of genetic variability in natural populations (Agarwal et al. 2008). Among the different molecular markers, the first to be established were the isozymes in the $60 \mathrm{~s}$ (Lewontin \& Hubby 1966). Isozyme markers have been widely used in different genetic studies in the genus Oryza, including studies of population genetics aiming at characterizing the diversity and genetic structure (Glaszmann 1988, Barbier 1989, Morishima \& Barbier 1990, Akimoto et al. 1998, Gao et al. 2000, Gao et al. 2002a, Veasey et al. 2008). This marker is relatively simple and cheap, and presents a codominant nature and known genetic control. However, its use is limited due to the low number of loci and alleles per locus detected, to post-translational modifications, tissue-specific forms, modifications in response to environmental conditions and to the developmental stage of the individual (Murphy et al. 1990).

With the advent of PCR in the late 1980s, which made the analysis and genotyping straightforward, microsatellites, characterized by high heterozygosity and the presence of multiple alleles, became the marker of choice in genome mapping and also in population genetics studies and related areas (Ellegren 2004). Microsatellites or simple sequence repeats (SSRs) consist of repeated tandem sequences with motifs of one to four base pairs. The advantages of this marker are the codominant nature, high frequency and random distribution in genomes and the high polymorphism it usually shows (Schlötterer 2004). Microsatellites have been used in several conservation and genetic diversity studies in wild rice species (Gao et al. 2002b, Zhou et al. 2003, Gao 2004, Gao 2005, Gao et al. 2006, Xu et al. 2006, Wang et al. 2008), and specifically in studies of Oryza glumaepatula natural populations, including the genetic structure and diversity (Brondani et al. 2005, Karasawa et al. 2007a, Silva et al. 2007, Vaz et al. 2009), the mating system determination (Karasawa et al. 2007b, Vaz et al. 2009), genetic mapping (Brondani et al. 2001) and phylogeny (Bautista et al. 2001).

Studies comparing genetic structure of natural populations with these two markers (isozymes and microsatellites) have been conducted for quite a few species, such as Sorghum bicolor (Djé et al. 1999), Elymus caninus 
(Sun et al. 2001), oaks (Quercus spp.) (Curtu et al. 2007), and Euterpe edulis (Conte et al. 2008). But the only report to-date comparing isozymes and microsatellite markers in the genus Oryza was conducted for O. rufipogon, a predominantly cross-pollinated species, studying genetic structure and genetic diversity parameters of natural populations (Gao et al. $2002 b$ ). Therefore, in order to provide a better comprehension of the results obtained and a comparison between codominant markers which will help choose tools for future studies in natural populations of $O$. glumaepatula, this study used both isozyme and microsatellite markers to assess (1) the level and distribution of genetic diversity; (2) the distribution of this diversity within and among populations, pointing to similarities and divergences; and (3) evaluating the relative importance of the results for studies of population genetics and conservation, considering the same set of populations and individuals of $O$. glumaepatula.

\section{MATERIALS AND METHODS}

Populations studied and sampling: Thirteen O. glumaepatula populations were assessed in this study, belonging to the wild rice collection in the Genetics Department of the Luiz de Queiroz College of Agriculture, University of São Paulo. The populations were selected from three regions in Brazil: (I) Amazon region, in Amazonas and Roraima States, with eight populations originating from the Purus, Solimões, Japurá, Tapajós, Negro and Branco River basins; (II) Xingu region, in Goiás State, which also belongs to the Amazon region but will be referred to in this study as the Xingu region, with one population collected at the Xingu River basin, located far from the other Amazonian populations; (III) Pantanal region, in Mato Grosso do Sul State, with four populations from the Paraguay River basin and one from Taquari River basin, which belong to the Pantanal ecosystem (Table 1, Fig. 1). These populations were sampled during two expeditions to the Rio Negro basin in 1992 and of the Rio Solimões basin in 1993 (Ando 1994), except for the Xingu population included in the collection more recently. During field collection, populations were sampled on an individual plant basis (Ando 1994). Since then these population samples have been maintained in refrigerators at $-4^{\circ} \mathrm{C}$, inside plastic boxes with

TABLE 1

Oryza glumaepatula populations assessed in this study and details of their origins

\begin{tabular}{|c|c|c|c|c|c|}
\hline Population & $\begin{array}{c}\text { Individuals per } \\
\text { population (Mean) }\end{array}$ & $\begin{array}{l}\text { Hydrographic } \\
\text { basin }\end{array}$ & River & Lake & Geographic location \\
\hline XI-1 & 24 Isoz; 27.4 SSR & Xingu & Xingu & Piulaga & $12^{\circ} 14^{\prime} \mathrm{S}-53^{\circ} 35^{\prime} \mathrm{W}$ \\
\hline PG-1 & 30 Isoz; 35.0 SSR & Paraguay & Paraguay & Pantanal & $19^{\circ} 01^{\prime} \mathrm{S}-57^{\circ} 30^{\prime} \mathrm{W}$ \\
\hline PG-2 & 21 Isoz; 16.6 SSR & Paraguay & Paraguay & Pantanal & $19^{\circ} 00^{\prime} \mathrm{S}-57^{\circ} 41^{\prime} \mathrm{W}$ \\
\hline PG-3 & 27 Isoz; 10.3 SSR & Paraguay & Corumbá & - & $18^{\circ} 59^{\prime} \mathrm{S}-57^{\circ} 37^{\prime} \mathrm{W}$ \\
\hline PG-4 & 22 Isoz; 29.9 SSR & Paraguay & Taquari & - & $19^{\circ} 15^{\prime} \mathrm{S}-57^{\circ} 13^{\prime} \mathrm{W}$ \\
\hline JA-4 & 19 Isoz; 35.4 SSR & Japurá & Japurá & Cuiucuiú & $02^{\circ} 02^{\prime} \mathrm{S}-65^{\circ} 07^{\prime} \mathrm{W}$ \\
\hline SO-6 & 25 Isoz; 16.7 SSR & Solimões & Solimões & Manacapuru & $03^{\circ} 11^{\prime} \mathrm{S}-60^{\circ} 47^{\prime} \mathrm{W}$ \\
\hline SO-17 & 30 Isoz; 16.1 SSR & Solimões & - & Coari & $04^{\circ} 02^{\prime} \mathrm{S}-63^{\circ} 15^{\prime} \mathrm{W}$ \\
\hline SO-21 & 23 Isoz; 12.0 SSR & Solimões & - & Mamiá & $04^{\circ} 15^{\prime} \mathrm{S}-63^{\circ} 03^{\prime} \mathrm{W}$ \\
\hline PU-1 & $21 \mathrm{Isoz} ; 29.7 \mathrm{SSR}$ & Purus & Purus & - & $03^{\circ} 49^{\prime} \mathrm{S}-61^{\circ} 25^{\prime} \mathrm{W}$ \\
\hline NE-18 & 24 Isoz; 29.1 SSR & Branco & Branco & - & $01^{\circ} 53^{\prime} \mathrm{S}-61^{\circ} 22^{\prime} \mathrm{W}$ \\
\hline NE-26 & 23 Isoz; 21.6 SSR & Negro & Carabinani & - & $01^{\circ} 54^{\prime} \mathrm{S}-61^{\circ} 23^{\prime} \mathrm{W}$ \\
\hline TA-1 & 18 Isoz; 32.4 SSR & Tapajós & Tapajós & - & $02^{\circ} 26^{\prime} \mathrm{S}-54^{\circ} 42^{\prime} \mathrm{W}$ \\
\hline
\end{tabular}

1. Isoz: isozyme markers; SSR: microsatellite markers. 


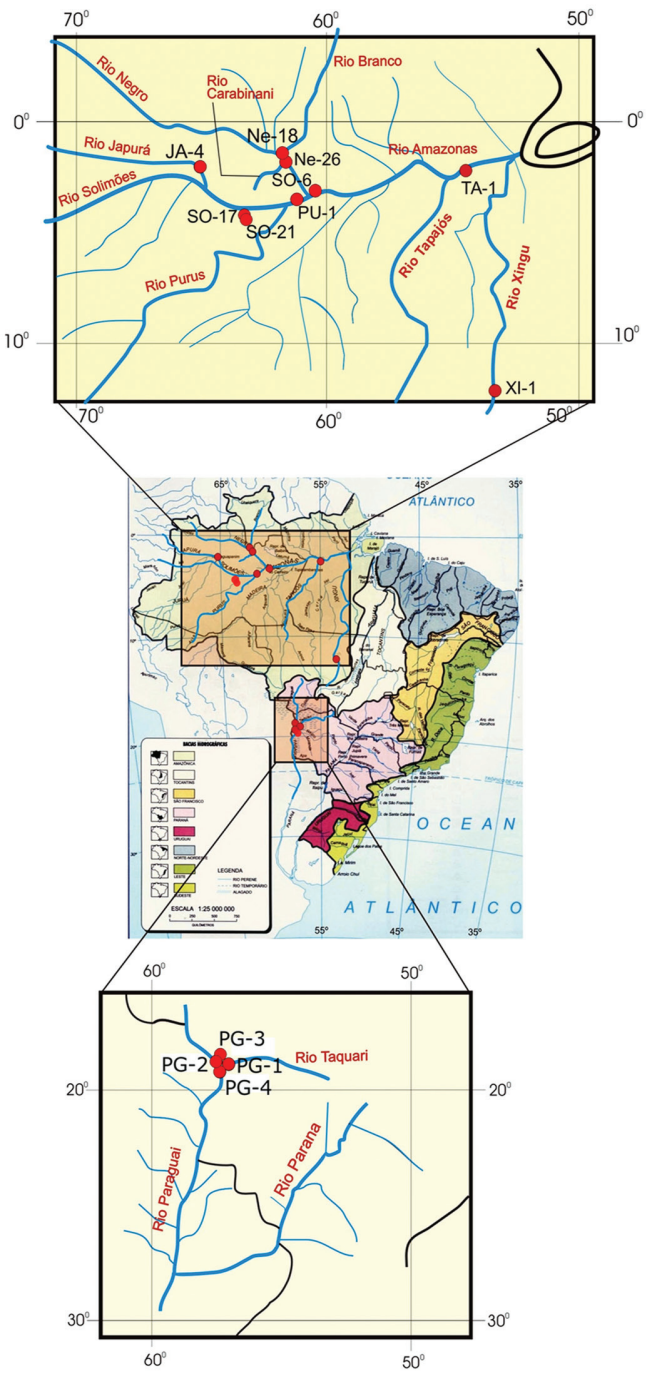

Fig. 1. Brazil showing the localization of the 13 Oryza glumaepatula populations, described in table 1 .

silica to avoid humidity, and have not been previously multiplied.

Each population sample in the collection is maintained as a set of maternal progenies, each progeny having been collected from an open-pollinated panicle of an individual plant in the field. For the analysis in this study, a bulk sample was obtained from each population, by sampling two to three seeds of each individual plant, up to a set of 50 seeds. These seeds were germinated in square plastic Gerboxes $(11 \times 11 \mathrm{~cm})$ with damp tissue paper at a temperature of $27 \pm 5^{\circ} \mathrm{C}$ in the dark. Germinated seeds were transplanted to pots in the greenhouse where they were grown up to adult stage. Each population was composed, on average, of 30 individuals.

DNA extraction and amplification of SSR loci: Total genomic DNA was extracted from adult lyophilized leaves of individual plants using the CTAB method according to Hoisington et al. (1994), modified by Karasawa et al. (2007a). DNA was quantified on $4 \%(\mathrm{w} / \mathrm{v})$ polyacrylamide gels and bands were revealed using the silver nitrate staining procedure (Bassam et al. 1991). Eight SSR loci (OG22, OG-26, OG-27, OG-29, OG-36, OG-39, OG-42 e OG-63), developed by Brondani et al. (2001), were used in this study (Table 2).

For each PCR reaction, 30ng of genomic DNA from individual plants were used in a $12 \mu \mathrm{L}$ volume containing $0.3 \mu \mathrm{M}$ of each primer, $0.25 \mathrm{mM}$ of each dNTP, $1.5 \mathrm{mM}$ of $\mathrm{MgCl}_{2}, 10 \mathrm{mM}$ Tris- $\mathrm{HCl}$, and 0.6 unit of Taq DNA polymerase enzyme (Invitrogen, Eugene, Oregon, USA). The reactions were performed in a Primus 96 Thermocycler with 4 min initial denaturation at $94^{\circ} \mathrm{C}, 30$ subsequent cycles $(1$ $\min$ at $94^{\circ} \mathrm{C}, 1 \mathrm{~min}$ at $54^{\circ} \mathrm{C}, 56^{\circ} \mathrm{C}$ or $60^{\circ} \mathrm{C}, 1$ min elongation at $72^{\circ} \mathrm{C}$ ), followed by a final elongation of $5 \mathrm{~min}$ at $72^{\circ} \mathrm{C}$. Amplified products were electrophoresed on $6 \%$ non-denaturing polyacrylamide gels $(4 \mathrm{~cm} / \mathrm{V}$, for three hours). Amplified fragments were visualized using silver staining procedure (Bassam et al. 1991).

Isozyme analyses procedures: Isozyme analyses were conducted in polyacrylamide gels, under a discontinuous system. The gel and electrode buffers used were a basic buffer (Hames 1996), with $\mathrm{pH} 8.8$ for the $5.5 \%$ resolving gel and $\mathrm{pH} 6.8$ for the $3.5 \%$ stacking gel.

The newest expanded leaves $(200 \mathrm{mg})$ were used for enzyme extraction of each plant. The leaves were ground in liquid nitrogen in microcentrifuge tubes using a power homogenizer, adding $1 \mathrm{~mL}$ of extraction buffer 1 (Alfenas 
TABLE 2

Primers developed for Oryza glumaepatula (Brondani et al. 2001) used in this study

\begin{tabular}{|c|c|c|c|c|c|c|c|}
\hline Loci & Primer sequences & Chrom. & bp & $\mathrm{T}_{\mathrm{a}}\left({ }^{\circ} \mathrm{C}\right)$ & $A$ & $H_{o}$ & $H_{e}$ \\
\hline OG 22 & $\begin{array}{l}\text { (F) GCCATCCATTCTTACCAG } \\
\text { (R) CACAGGTGTGGTGCTCA }\end{array}$ & 12 & $165-265$ & 56 & 21 & 0.101 & 0.804 \\
\hline OG 26 & $\begin{array}{l}\text { (F) CATGGTGCCGATTACGGT } \\
\text { (R) CATCTCCATCGCGGTCAT }\end{array}$ & 10 & $95-120$ & 60 & 5 & 0.025 & 0.751 \\
\hline OG 27 & $\begin{array}{l}\text { (F) TCGGACGTGGCATATGA } \\
\text { (R) CTGTTCCGAGCGAGAGT }\end{array}$ & 9 & $120-210$ & 54 & 16 & 0.083 & 0.882 \\
\hline OG 29 & $\begin{array}{l}\text { (F) GACCAGTTCACCATGCAG } \\
\text { (R) GAGTGAGGCAGCAAGACA }\end{array}$ & 1 & $80-125$ & 60 & 10 & 0.121 & 0.814 \\
\hline OG 36 & $\begin{array}{l}\text { (F) AACGTTCATCGGTTCTGG } \\
\text { (R) TGCTTGCCAGGTTATTCC }\end{array}$ & 4 & $160-190$ & 56 & 8 & 0,106 & 0.793 \\
\hline OG 39 & $\begin{array}{l}\text { (F) GCGTACTAGGCCATGATA } \\
\text { (R) TCCACGTAAGAACACTCG }\end{array}$ & 3 & $250-280$ & 56 & 6 & 0.042 & 0.742 \\
\hline OG 42 & $\begin{array}{l}\text { (F) TGCAGGCTCTGAGCTAC } \\
\text { (R) AGAACAGATCTTGCCGTC }\end{array}$ & 5 & $420-440$ & 56 & 6 & 0.043 & 0.536 \\
\hline OG 63 & $\begin{array}{l}\text { (F) CAGGGGACAAGCACATA } \\
\text { (R) TAGACGATGTCGAGAAGG }\end{array}$ & 2 & $100-150$ & 56 & 9 & 0.155 & 0.766 \\
\hline Mean & & & & - & 10.12 & 0.085 & 0.761 \\
\hline
\end{tabular}

Chrom.: chromosome location; pb: fragment size; $\mathrm{T}_{\mathrm{a}}$ annealing temperature; $A$ - number of alleles per locus; $H_{o}$ - observed heterozygosity; $H_{e}$ - gene diversity.

et al. 1991), leaving out diethyldithiocarbamic acid (DIECA) and 2-mercaptoethanol. The extract was centrifuged at $18000 \mathrm{~g}$ for $20 \mathrm{~min}$ at $4^{\circ} \mathrm{C}$. Afterwards, $130 \mu \mathrm{L}$ of the supernatant were diluted in $150 \mu \mathrm{L}$ of a solution containing Tris- $\mathrm{HCl} \mathrm{pH} 6.8$ and Coomassie blue, the latter component indicating the protein migration in the gel. This amount of extract was sufficient for four gels, which allowed the assessment of 38 individuals each. The same control plant was added to each gel as a marker. The voltage was set at $50 \mathrm{~V}$ during three hours, adjusted to $100 \mathrm{~V}$ for the next 13 hours, usually staying overnight at $4^{\circ} \mathrm{C}$.

From a total of 10 promising enzymatic systems (Veasey et al. 2008), four were selected in this study due to the presence of higher band resolution: aspartate aminotransferase (AAT; E.C. 2.6.1.1, with three loci), phosphoglucomutase (PGM; E.C. 2.7.5.1), shikimate dehydrogenase (SKD; E.C. 1.1.1.25) and glutamate dehydrogenase (GDH; E.C. 1.4.1.2).

For the statistical analysis, the GDA program (Lewis \& Zaykin 2000) was used to estimate allelic and genotypic frequencies, number of alleles per locus $(A)$, observed heterozygosities $\left(H_{o}\right)$, gene diversity $\left(H_{e}\right)$, and fixation indices $(f)$. Genotypic frequencies obtained from both markers were submitted to Fisher's exact test considering the Hardy-Weinberg equilibrium, as defined by Weir (1996), using the TFPGA software (Miller 1997).

Wright's F statistics were estimated considering a random model, defined according to Weir (1996), where the sampled populations were considered representative of the species and with a common evolutionary history. These estimates $\left(F_{I S}, F_{S T}\right.$ e $\left.F_{I T}\right)$ were obtained using the software $\mathrm{F}_{\mathrm{STAT}}$ (Goudet 1995). Confidence intervals $(95 \%)$ were also obtained for each of these estimates. Private alleles were also identified with the GDA program (Lewis \& Zaykin 2000).

Considering that the mutation process in microsatellite loci is not in line with the expectations under the infinite alleles model with low rates, the analogue of $F_{S T}$ parameter (Slatkin 1995) developed specifically for 
microsatellite data $\left(R_{S T}\right)$ was also estimated. Parameters $R_{S T}$ and gene flow $(\mathrm{Nm})$ were estimated using the $\mathrm{R}_{\mathrm{ST}} \mathrm{Cal}$ program (Goodman 1997). Dendrograms were constructed from Nei's genetic distances matrix and the UPGMA clustering criteria, using the TFPGA software (Miller 1997).

Patterns of spatial variation were analyzed using Pearson's coefficient of correlation (r) between Nei's genetic distances matrix (Nei 1978) and the matrix of geographic distances (shortest distance between two given points on the map) between populations, using NTSYSpc (Rohlf 1992). Significance of these correlations was tested by Mantel's statistic Z (Mantel 1967), using 1000 random permutations. Average apparent outcrossing rate was estimated considering the relation $\bar{t}_{a}=\left(1-F_{I S}\right) /\left(1+F_{I S}\right)$. The parameter $\bar{t}_{a}$ was also estimated for each population $\left[\bar{t}_{a}=(1-f) /(1+f)\right]($ Weir 1996)

\section{RESULTS}

Genetic diversity levels: All SSR loci showed polymorphism (Table 2) while isozymes were monomorphic for two of the six loci, Aat3 and Gdh (Table 3). A total of 81 alleles were found for the SSR markers, varying from five to 21 alleles per locus (Table 2), while 11 alleles were found for the isozyme markers, varying from one to three alleles per locus (Table 3). For both markers, the mean expected heterozygosity or gene diversity was higher than the mean observed heterozygosity

TABLE 3

Isozyme loci used in this study with their respective number of alleles per locus (A), observed heterozygosity $\left(H_{o}\right)$ and gene diversity $\left(H_{e}\right)$

\begin{tabular}{cccc} 
Loci & $\mathrm{A}$ & $\mathrm{H}_{\mathrm{o}}$ & $\mathrm{H}_{\mathrm{e}}$ \\
Aat1 & 2 & 0.012 & 0.481 \\
Aat2 & 2 & 0.007 & 0.393 \\
Aat3 & 1 & 0.000 & 0.000 \\
Skdh & 2 & 0.007 & 0.283 \\
Pgm & 3 & 0.012 & 0.326 \\
Gdh & 1 & 0.000 & 0.000 \\
Mean & 1.83 & 0.007 & 0.247 \\
\hline
\end{tabular}

$\left(H_{o}=0.085\right.$ and $H_{e}=0.761$ for SSR; $H_{o}=0.007$ and $H_{e}=0.247$ for isozymes) (Tables 2 and 3).

Considering each population, JA-4 was monomorphic for all eight SSR loci, while populations PG-3, SO-6, PU-1 and NE-26 were monomorphic for the six isozyme loci. The average polymorphism rate was $20 \%$ for isozymes and $71 \%$ for microsatellites (Table 4). The average number of alleles per locus per population $(\bar{A})$ was 1.20 and 2.83 , with means over loci of 1.83 and 10.12, respectively, and the average number of alleles per polymorphic locus $\left(\bar{A}_{p}\right)$ of 1.83 and 3.17 , respectively, for isozymes and microsatellites (Table 4).

No private alleles were detected for the isozyme markers, probably due to the small number of alleles and small number of enzyme loci, whereas the SSR markers were effective in detecting private alleles (Fig. 2). There was only one private allele detected in the Xingu region, 19 in the Amazon and eight in the Pantanal region (Fig. 2B). At the population level, the number of private alleles detected with SSR varied from 0 to 8 (Fig. 2A).

The average observed heterozygosity $\left(H_{o}\right)$ and gene diversity $\left(H_{e}\right)$ assessed with isozymes and SSR markers for the 13 populations were 0.006 and 0.056 , and 0.081 and 0.351 , respectively (Table 4). On the other hand, when considering $H_{o}$ and $H_{e}$ as the mean over loci, we detected $H_{o}^{o}=0.007$ and 0.085 , and $H_{e}=0.247$ and 0.766 for isozymes and SSR, respectively. The tendency for the microsatellites to detect higher $H_{o}$ and $H_{e}$ levels, within each of the three regions, was maintained (Table 5). The apparent outcrossing rate $\left(t_{a}\right)$ estimated by these markers showed surprising differences at the populational (Table 4) and regional (Table 5) levels, but both markers showed lower levels in the Amazon region (1.9\% and $2.8 \%$ ), while the highest levels occurred in the Pantanal region, with $5.2 \%$ and $10.5 \%$, respectively, for isozymes and microsatellites (Table 5). However, the markers were not in agreement in the case of the Xingu region, represented by the XI-1 population, which registered absence of outcrossing when assessed with isozymes but showed outcrossing rates of $54.1 \%$ when 


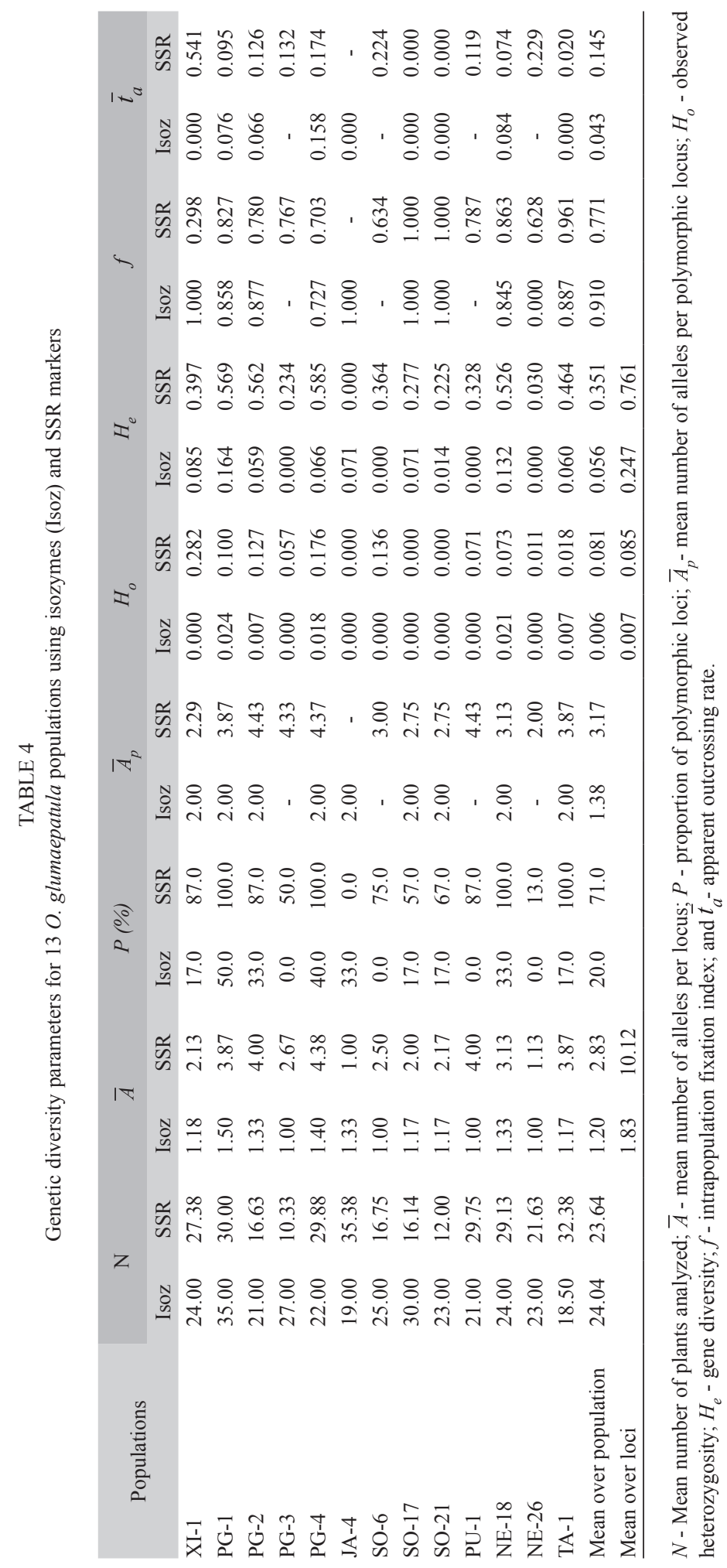



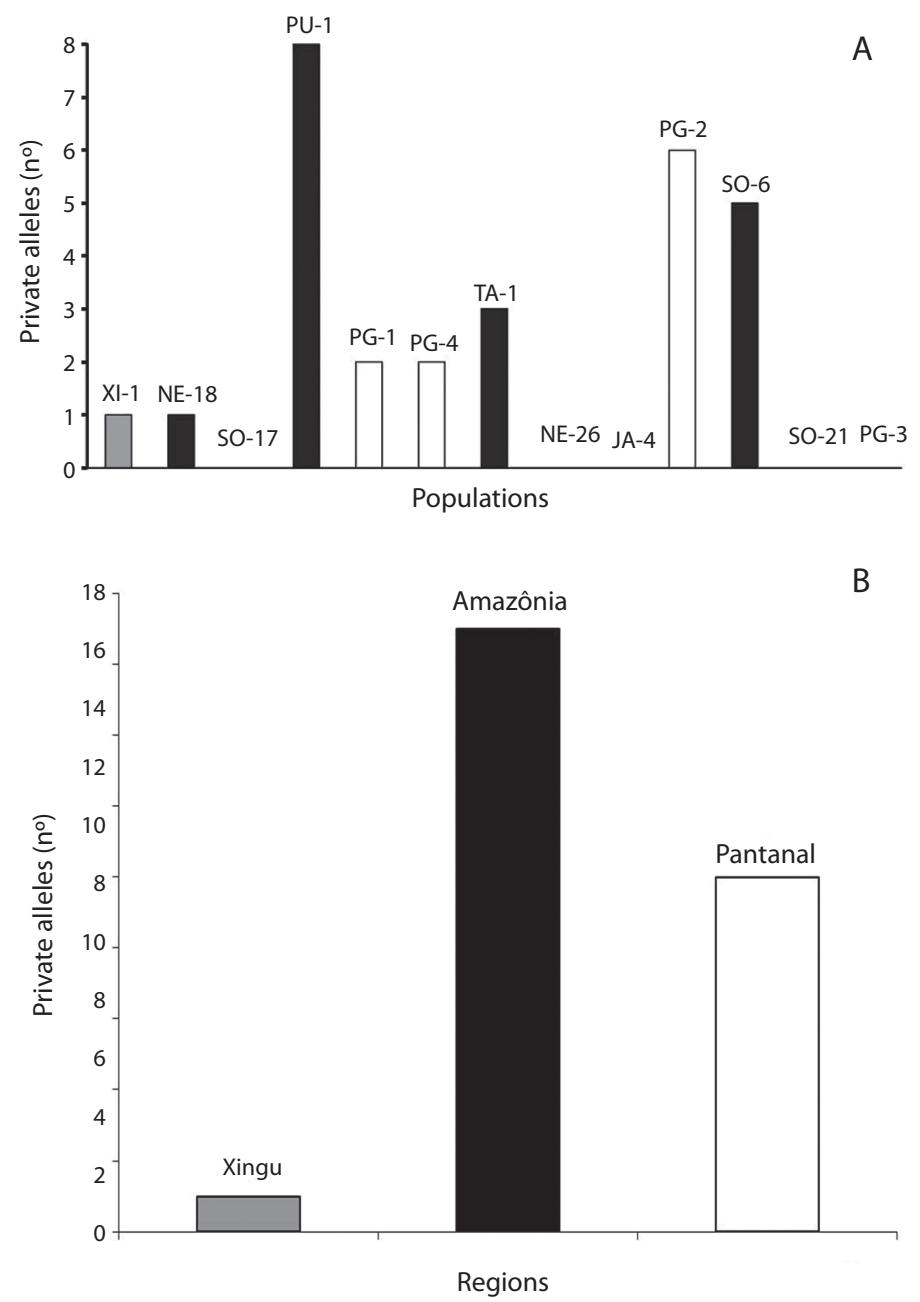

Fig. 2. Number of private alleles for 13 Oryza glumaepatula populations (A) and three regions (B) assessed with microsatellite markers.

TABLE 5

Genetic diversity parameters for each of the three regions considered in this study using isozymes (Isoz) and SSR markers

\begin{tabular}{lccccccccc}
\multirow{2}{*}{ Region } & \multicolumn{2}{c}{$H_{0}$} & \multicolumn{3}{c}{$H_{e}$} & \multicolumn{3}{c}{$f$} & \multicolumn{3}{c}{$\bar{t}_{a}$} \\
& Isoz & SSR & Isoz & SSR & Isoz & SSR & Isoz & SSR \\
Xingu & 0.000 & 0.282 & 0.085 & 0.397 & 1.000 & 0.298 & 0.000 & 0.541 \\
Amazon & 0.004 & 0.039 & 0.099 & 0.720 & 0.963 & 0.945 & 0.019 & 0.028 \\
Pantanal & 0.014 & 0.133 & 0.147 & 0.693 & 0.902 & 0.810 & 0.052 & 0.105 \\
\hline
\end{tabular}

$H_{o}$ - observed heterozygosity; $H_{e}$ - gene diversity; $f$ - fixation index; $\bar{t}_{a}$ - apparent outcrossing rate 
analyzed with microsatellites. These results showed that, in general, SSR markers are more efficient than isozymes to detect outcrossing events both at the populational and regional levels and that, except for the Xingu region, with only one population assessed, this species presents a mixed mating system with predominance of self-fertilization.

Genetic population structure: Mean inbreeding registered within each population (f) was higher, in general, for the isozymes (0.910) when compared to microsatellites (0.771) (Table 4). This tendency was maintained for both markers also at the regional level (Table 5). The estimates of $\mathrm{F}$ statistics revealed that total inbreeding coefficient $\left(F_{I T}\right)$ in this species is very high, 0.974 for isozymes and 0.895 for microsatellites (Table 6), and that the main factor promoting the deviation from Hardy-Weinberg equilibrium is the mating system $\left(F_{I S}=0.899\right.$ and 0.774 , respectively, for isozymes and microsatellites). However, although of a lower magnitude, but also expressive, the genetic differentiation among populations $\left(F_{S T}\right)$ contributed for the total inbreeding levels observed, with the isozyme markers showing a value of 0.772 for this parameter, while the level registered for the SSR markers was 0.533 (or 0.631 for the corrected value of $R_{S T}$ ). On the other hand, the number of migrants per generation $(\mathrm{Nm}=1 / 4$ $\left[\left(1 / F_{S T}\right.\right.$ or $\left.\left.\left.R_{S T}\right)-1\right]\right)$ observed for both markers was small, only 0.074 for the isozymes and 0.146 for the SSR marker (Table 6).
The cluster analysis, based on Nei's genetic distances (Nei 1978) and the UPGMA method, showed that isozyme data tended to exhibit clustering according to the origins of the populations, with two clear groups: the Amazon populations in the first group and the Pantanal populations as well as the Xingu population (as a sub-group) in the second group. For Aat-1 and Aat-2 loci, different alleles predominated in each of the two regions, Pantanal and the Amazon (Fig. 3A). The Xingu population (XI-1) and the Pantanal populations shared the same allele frequencies for these two loci, which explains its proximity to the Pantanal populations in the dendrogram. However, it was classified in a sub-group within the second group, differing from the Pantanal populations for presenting a fixed $a 2$ allele at $S k d-1$ locus and from all the others for presenting a high frequency of the $a 3$ allele at Pgm-1 locus.

However, data from microsatellites tended to exhibit a random clustering, not in agreement with the geographic origins (Fig. 3B). These results were confirmed in the correlation tests between genetic and geographic distances obtained for each marker. In this sense, correlations between genetic and geographic distances showed a positive and significant result $(\mathrm{r}=0.6594, \mathrm{p}<0.05)$ when estimated with isozymes and an absence of correlation $(r=-0.1789, p>0.05)$, when estimated with microsatellites. On the other hand, no correlation $(\mathrm{r}=-0.0005, \mathrm{p}>0.05)$ was found between the two markers, when their genetic distances were analyzed.

TABLE 6

Wright's F statistics estimates, number of migrants per generation using $F_{S T}\left(N m_{l}\right)$ or $R_{S T}\left(N m_{2}\right)$ for isozymes and microsatellites, for the Oryza glumaepatula populations

\begin{tabular}{lcccccccccc} 
& \multicolumn{4}{c}{ Isozymes } & \multicolumn{1}{c}{ Microsatellites } \\
& $F_{I T}$ & $F_{I S}$ & $F_{S T}$ & $N m_{1}$ & $F_{I T}$ & $F_{I S}$ & $F_{S T}$ & $R_{S T}$ & $N m_{I}$ & $N m_{2}$ \\
Under all loci & 0.974 & 0.899 & 0.772 & 0.074 & 0.895 & 0.774 & 0.533 & 0.631 & 0.219 & 0.146 \\
Upper (CI 95\%) & 0.981 & 0.923 & 0.875 & - & 0.929 & 0.833 & 0.597 & - & - & - \\
Lower (CI 95\%) & 0.966 & 0.813 & 0.619 & - & 0.860 & 0.704 & 0.472 & - & - & - \\
\hline
\end{tabular}

$N m_{1=}$ Based on $F_{S T} ; N_{2=}$ Based on $R_{S T} ; \mathrm{CI} 95 \%=95 \%$ confidence interval. 

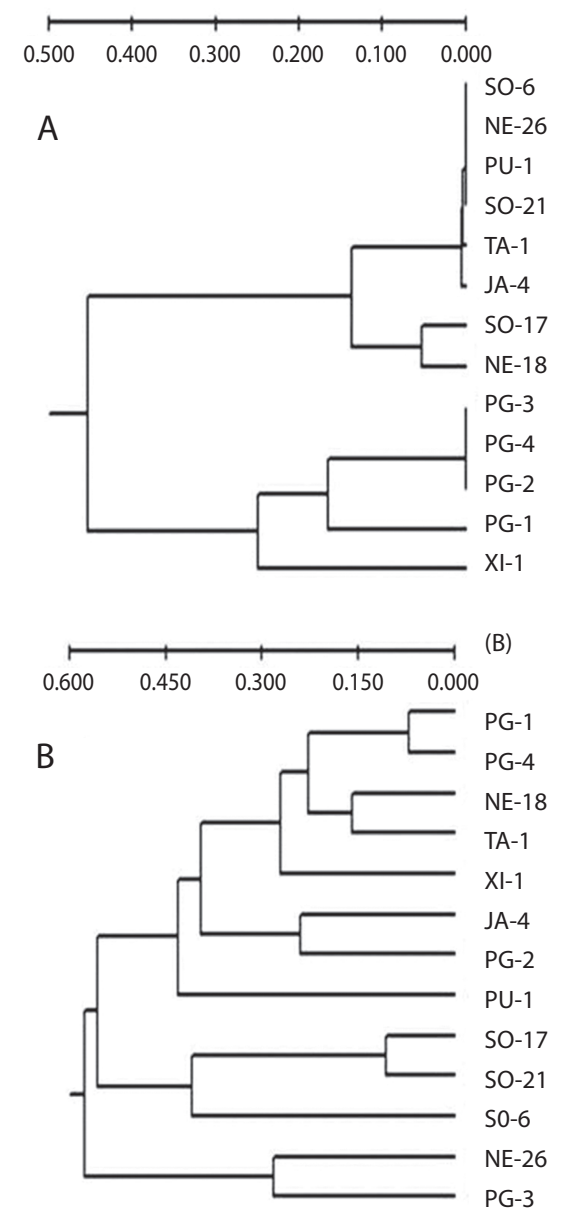

Fig. 3. Pattern of genetic divergence among 13 Oryza glumaepatula populations based on the UPGMA clustering method and Nei's genetic distances (Nei, 1978) for both isozyme (A) and microsatellite (B) markers.

\section{DISCUSSION}

Genetic diversity levels: This study compared the levels of diversity assessed with isozymes and microsatellite markers in $13 O$. glumaepatula populations in order to establish the potential of each marker for a predominantly inbreeding wild rice species. The results of the analysis of microsatellite and isozyme loci are consistent with the principles of each marker, considering the fact that microsatellites showed a wide range of alleles at each locus whereas isozymes showed only one to three alleles per locus. Possibly, the adaptive nature of some genes that govern the production of proteins, when under environmental effect, tends to express monomorphism within populations (Schlötterer 2004, Lowe et al. 2007). Another reason for the relatively fewer apparent alleles in isozymes is the ineffectiveness of most mutations in changing the electrophoretic mobility of the bands (i. e., the visualization of different alleles), since only a few aminoacid changes modify the net electric charge of the proteins, whereas most length changes in SSRs cause their band speed to vary. Additionally, the types of mutation process that give rise to SSR alleles and to isozyme alleles are different and the former is more common. On the other hand, microsatellites are usually found in non-coding repetitive DNA regions and the high mutation rate through gain and/or loss of repeats (Goldstein \& Schlötterer 2000) can be explained by their usual neutrality. Recently, however, increasingly more microsatellites have been found and characterized within protein-coding genes and their untranslated regions (UTRs), which subjects them to stronger selective pressure than other genomic regions because of their functional importance (Li et al. 2004). In our study, however, most of the SSR loci used (six out of eight loci) were not located within genes (Karasawa et al. 2007b). But irrespective of their location in the genome, polymorphism is common in SSR markers while the presence of monomorphism tends to be a rare condition (Panaud et al. 1995).

In this study, isozymes showed only $42.4 \%$ to $43.5 \%$ of the microsatellites' diversity detected in the parameters average number of alleles $(\bar{A})$ and average number of alleles per polymorphic locus $\left(\bar{A}_{p}\right)$, respectively. Similarly, we found that microsatellites detected private alleles, whereas no private alleles were found with isozyme markers, which may be due to a lower number of apparent alleles per locus and a lower number of loci used in this study.

The levels of observed heterozygosity $\left(H_{o}\right)$ and gene diversity $\left(H_{e}\right)$ assessed with isozymes represented, on average, $7.4 \%$ and $15.9 \%$ of those observed with microsatellites, 
respectively. However, when gene diversity was considered over loci we could verify that the amount is higher than at the population level. This fact occurred because the split of the ancestral population led to a fixation of specific alleles in each population. This reduction in the number of alleles in each population, from 1.83 to 1.20 and from 10.12 to 2.83 , respectively for isozymes and microsatellites, led to lower gene diversity at the population level. Microsatellites are considered genetically more informative than other markers, especially when dealing with populations with low genetic diversity content at the DNA level (Paetkau et al. 1995). The low gene diversity $\left(H_{e}\right)$ levels in this species has already been shown in previous studies with isozymes, revealing variations from 0.044 to 0.060 (Akimoto et al. 1998, Buso et al. 1998, Veasey et al. 2008), as compared with microsatellites with higher levels, ranging from 0.113 to 0.491 (Brondani et al. 2005, Karasawa et al. 2007a, Silva et al. 2007). Thus, considering the information obtained in this study with isozymes and microsatellites, we can conclude that microsatellite markers are in fact more informative as they were able to detect higher levels of intra-population diversity in this species. Gao et al. (2002b) also found higher levels of genetic variation with microsatellite loci than isozyme loci when studying $O$. rufipogon populations from China. Similarly, higher levels of polymorphism revealed by microsatellites when compared to isozymes were found in natural populations of Euterpe edulis Mart. in Brazil (Conte et al. 2008), oaks (Quercus spp.) in West-Central Romania (Curtu et al. 2007), in a natural Elymus caninus (L.) L. population from Denmark (Sun et al. 2001) and in sorghum (Sorghum bicolor L.) landraces in North-Western Morocco (Djè et al. 1999).

Population genetic structure: Isozyme markers showed similar inbreeding levels $(f)$ as microsatellites for populations, regions and for total inbreeding of the species $\left(F_{I T}\right)$, except for the Xingu population. The existence of inbreeding within populations showed, with both markers, that this species has an inbred maternal family structure within populations and that this structure was established primarily by the reproductive system $\left(F_{I S}\right)$, and that most of the total diversity is located among families within populations. In fact, the reproductive system of this species, classified as mixed with predominance of self-fertilization (Karasawa et al. 2007b, Vaz et al. 2009), seems to have a predominant effect on differentiation within and between populations. Both markers are also congruent in that the fragmentation of the species led to a considerable and important amount of genetic diversity among populations $\left(F_{S T}\right)$. Gao et al. (2002b) also found an agreement in this type of result with both markers, but in $O$. rufipogon the greatest effect was in the formation of genetic structure due to fragmentation $\left(F_{S T}\right)$. Measures of genetic structure, such as Wright's F statistics, or Nei's coefficient of gene differentiation $\left(G_{S T}\right)$ (Nei 1973), were similar for the two sets of markers (isozymes and SSR) assessed in natural populations of Sorghum bicolor (Djé et al. 1999), Elymus caninus (Sun et al. 2001) and Euterpe edulis (Conte et al. 2008).

Previous studies on genetic structure conducted in the genus Oryza have recorded several $F_{S T}\left(G_{S T}\right)$ values, but largely agree that the mode of reproduction of the species has generated prominent effect on the differentiation observed. In O. glumaepatula, studies using allozymes showed $F_{S T}$ values of 0.346 (Akimoto et al. 1998), 0.310 (Buso et al. 1998) and 0.763 (Veasey et al. 2008), while those using microsatellites showed values such as 0.847 (Brondani et al. 2005), 0.491 (Karasawa et al. 2007a) and 0.715 (Silva et al. 2007). In progeny studies, the value recorded with microsatellites was 0.451 for the parental populations, and 0.284 for the families of these populations (Karasawa et al. 2007b).

$O$. rufipogon studies with isozymes showed genetic structure levels $\left(F_{S T}\right)$ dependent on the developmental stages (seed, young and adults plants) and the life cycle (annual or perennial). Annual populations showed $F_{S T}$ values varying from 0.085 to 0.208 for seeds, from 0.087 to 0.145 for young plants and 0.193 
for adults, while among the perennial populations higher values were found, ranging from 0.327 to 0.366 at the seed level, from 0.129 to 0.356 for young plants and from 0.360 to 0.390 for the adults (Barbier 1989). Morishima \& Barbier (1990) obtained $F_{S T}$ values of 0.289 for intermediate populations, 0.396 for perennials and 0.600 for annuals. Gao et al. (2000) and Gao et al. (2002a) reported values such as 0.310 and 0.254 in perennial populations with isozymes. With microsatellites, Gao (2004) obtained an $F_{S T}$ value of 0.246 , whereas when comparing isozymes and microsatellites, Gao et al. (2002b) obtained values of 0.468 for isozymes and 0.388 for microsatellites. Among Chinese $O$. officinalis perennial populations, an $F_{S T}$ value of 0.442 was reported (Gao 2005).

The results in our study with $O$. glumaepatula populations, comparing microsatellites $\left(F_{S T}=0.533\right)$ with isozymes $\left(F_{S T}=0.772\right)$, are in accordance with the results obtained by Gao et al. (2002b) for perennial outcrossing O. rufipogon populations, although these values were lower than those found in O. glumaepatula. It is difficult to conclude whether the heterogeneity of the $F_{S T}$ values found with isozyme loci compared with microsatellites was caused by stochastic processes or as an indirect effect of selection. According to a survey by Frankel et al. (1995), the genetic diversity among populations $\left(G_{S T}\right)$ with isozymes should be lower in cross-pollinating and perennial plants, and higher in autogamous and annual plants, which may explain the results discussed above.

Due to the mode of reproduction of this species, the number of migrants $(\mathrm{Nm})$ estimated promoting gene flow among populations was small, only 0.074 for isozymes and 0.146 for microsatellites. Gene flow is important in the evolution of plant populations, because the geographical variation observed in morphology and gene frequencies of a species results from the balance between forces that act to cause local differentiation counterbalanced by forces that tend to produce homogeneous populations (Slatkin 1987).

Cluster analysis grouped the populations according to their geographical origin with isozymes, whereas a pattern of random clustering of populations not consistent with the geographical origin was observed for microsatellites. Djè et al. (1999) also found no concordance between the cluster analysis based on allozymes and the cluster based on microsatellites for sorghum landraces. Gao et al. (2002b), comparing data obtained with isozymes and microsatellites in O. rufipogon, found that information obtained by both markers were not completely correlated. The grouping of maternal plants of Elymus caninus based on isozymes and microsatellites were also not completely consistent with each other (Sun et al. 2001).

In our study, we verified a positive correlation between genetic and geographical distances for isozymes and a negligible negative correlation when estimated with microsatellites. A positive correlation between genetic and geographical distances, when the genetic markers are neutral, is frequently assumed as a result of limited gene flow between contiguous populations, while a lack of correlation may result from long-distance dispersal, geographic barriers or unlimited gene flow between contiguous populations. The positive correlation found with isozymes may thus be explained by gene flow dependent on geographic distance; the lack of correlation with microsatellites is more difficult to explain and could be due to the rapid allele turnover caused by the high mutation rate in the loci, which would have blurred the geographic pattern still visible with isozymes. When comparing the genetic distances obtained from both markers, the result was an absence of correlation. Therefore, inferences made from one of the markers cannot be considered for the other marker.

Our results showed that microsatellites generate a higher volume of intra-population genetic diversity information compared to those obtained with isozymes in this species. Microsatellites showed $130 \%$ more alleles and 3.5 times higher rate of polymorphism, being more effective, therefore, in the analysis of diversity in a predominantly inbreeding species. Therefore, the superiority of microsatellites 
in detecting intra-population diversity, private alleles and the relative agreement with isozymes considering the migrant levels between populations, make this an important marker in the study of population genetics and conservation. However, isozymes had the advantage in this study of clustering the populations according to their origins, which was not observed for microsatellites. As no correlation between genetic distances was obtained between the two markers, inferences made from one of the markers cannot be considered for the other marker.

In summary, it can be said that SSR markers showed more power for investigating neutral intra-population diversity, as expected. At the inter-population level, however, despite the relatively small number of loci used, isozymes led to better results, since clustering of populations agreed with the expectations based on the geographic distribution of the populations.

\section{ACKNOWLEDGMENTS}

This research was supported by grants and scholarships provided by Fundação de Amparo à Pesquisa do Estado de São Paulo (FAPESP) and Conselho Nacional de Desenvolvimento Científico e Tecnológico (CNPq). The authors wish to thank Professors Paulo Sodero Martins (in memoriam) and Akihiko Ando, from the Genetics Department at ESALQ/USP, and Hiroko Morishima (in memoriam), from the National Institute of Genetics, Mishima, Japan, for coordinating the projects through which the wild rice germplasm used in this study was collected. The authors also wish to thank the valuable contributions by two referees.

\section{RESUMEN}

El estudio de la estructura genética de poblaciones de plantas silvestres es esencial para su manejo y conservación. Varios marcadores de ADN e isoenzimas se han utilizado en este tipo de análisis. Con el fin de proporcionar una mejor comprensión de los resultados obtenidos y saber que marcador codominante elegir para futuros estudios en poblaciones naturales de Oryza glumaepatula, este trabajo busco evaluar y comparar dos marcadores de ADN, isoenzimas y microsatélites, en la diversidad y estructura genética de 13 poblaciones, destacando las similitudes y divergencias de cada marcador, así como la importancia relativa de los resultados en genética de poblaciones y conservación. Para los SSR, ocho loci SSR fueron evaluados, y los fragmentos se visualizaron utilizando el procedimiento de coloración con plata. Los análisis de isoenzimas se realizaron en geles de poliacrilamida, en los seis loci enzimáticos. Los loci SSR mostraron mayores niveles de diversidad genética que los loci isoenzimáticos, en promedio. La diferenciación genética entre los loci $\mathrm{SSR}\left(R_{S T}=0.631\right.$, equivalente a $\left.F_{S T}=0.533\right)$ fue inferior a la obtenida con las isoenzimas $\left(F_{S T}=0.772\right)$. Ambos marcadores mostraron alta desviación del equilibrio de Hardy-Weinberg $\left(F_{I S}=0.744\right.$ y 0.899 , respectivamente, para SSR e isoenzimas). La tasa media aparente de cruzamiento para SSR $\left(\bar{t}_{a}=0.14\right)$ fue mayor que la obtenida con isoenzimas $\left(\bar{t}_{a}=0.043\right)$, aunque ambos marcadores detectaron niveles más bajos en la tasa de fecundación cruzada para la Amazonia, en comparación con la región del Pantanal. La estimación de número de migrantes también fue mayor para los $\operatorname{SSR}(\mathrm{Nm}=0.219)$ que en isoenzimas $(\mathrm{Nm}=0.074)$. No se obtuvo ninguna correlación entre las distancias genéticas y geográficas para los SSR, y para las isoenzimas se obtuvo una correlación positiva entre las distancias genéticas y geográficas. Llegamos a la conclusión de que estos marcadores son divergentes en la detección de los parámetros de la diversidad genética en $O$. glumaepatula y que los microsatélites son más eficientes para detectar la información a nivel intrapoblacional, mientras que las isoenzimas son más potentes para detectar la diversidad entre poblaciones.

Palabras clave: estructura genética, flujo de genes, isoenzimas, SSR, sistema de cruzamiento.

\section{REFERENCES}

Agarwal, M., N. Shrivastava \& H. Padh. 2008. Advances in molecular marker techniques and their applications in plant sciences. Plant. Cell. Rep. 27: 617-631.

Akimoto, M., Y. Shimamoto \& H. Morishima. 1998. Population genetic structure of wild rice Oryza glumaepatula distributed in the Amazon flood area influenced by life-history traits. Mol. Ecol. 7: 1371-1381.

Alfenas, A.C., I. Peters, W. Brune \& G.C. Passador. 1991. Eletroforese de proteínas e isoenzimas de fungos e essências florestais. UFV, Viçosa, Brazil.

Ando, A. 1994. Outline of the project and field methods. In H. Morishima \& P.S. Martins (eds.). Investigations of plant genetic resources in the Amazon basin with the emphasis on the genus Oryza: Report of 1992/93 Amazon Project. The Monbusho International Scientific Research Program, Mishima, Japan and Research Support Foundation of the State of São Paulo, São Paulo, Brazil. 
Bassam, B.J., G. Caetano-Anolles \& P.M. Gresshof. 1991. Fast and sensitive silver staining of DNA in polyacrylamide gels. Anal. Biochem. 196: 80-83.

Bautista, N.S., R. Solis, O. Kamijima \& T. Ishii. 2001. RAPD, RFLP and SSLP analyses of phylogenetic relationships between cultivated and wild species of rice. Genes. Genet. Syst. 76: 71-79.

Barbier, P. 1989. Genetic variation and ecotypic differentiation in the wild rice species Oryza rufipogon. II Influence of the mating system and life-history traits on the genetic structure of populations. Jpn. J. Genet. 64: $273-285$.

Black, G.A. 1950. Os capins aquáticos da Amazônia. Boletim Técnico do Instituto Agronômico do Norte, 19. Notas sobre a flora neotrópica III. 96 p.

Brondani, C., R.P.V. Brondani, P.H.N. Rangel \& M.E. Ferreira. 2001. Development and mapping of Oryza glumaepatula-derived microsatellite markers in the interspecific cross Oryza glumaepatula x O. sativa. Hereditas 134: 59-71.

Brondani, R.P.V., M.I. Zucchi, C. Brondani, P.H.N. Rangel, T.C.O. Borba, P.N. Rangel, M.R. Magalhães \& R. Vencovsky. 2005. Genetic structure of wild rice Oryza glumaepatula populations in three Brazilian biomes using microsatellite markers. Genetica 125: 115-123.

Buso, G.S.C., P.H. Rangel \& M.E. Ferreira. 1998. Analysis of genetic variability of South American wild rice populations (Oryza glumaepatula) with isozymes and RAPD markers. Mol. Ecol. 7: 107-117.

Conte, R., M.S. Reis, A. Mantovani \& R. Vencovsky. 2008. Genetic structure and mating system of Euterpe edulis Mart. populations: a comparative analysis using microsatellites and allozyme markers. J. Hered. 99: 476-482.

Curtu, A.L., O. Gailing, L. Leinemann \& R. Finkeldey. 2007. Genetic variation and differentiation within a natural community of five oak species (Quercus spp.). Plant Biol. 9: 116-126.

Djé, Y., D. Forcioli, M. Ater, C. Lefèbvre \& C. Vekemans. 1999. Assessing population genetic structure of Sorghum landraces from North-western Morocco using isozyme and microsatellite markers. Theor. Appl. Genet. 99: 157-163.

Ellegren, H. 2004. Microsatellites: simple sequences with complex evolution. Nature Rev. Genet. 5: 435-444.

Frankel, O.H., A.H.D. Brown \& J.J. Burdon. 1995. The conservation of plant biodiversity. Cambridge University, Cambridge, United Kingdom.

Gao, L.Z. 2004. Population structure and conservation genetics of wild rice Oryza rufipogon (Poaceae): a region-wide perspective from microsatellite variation. Mol. Ecol. 13: 1009-1024.
Gao, L.Z. 2005. Microsatellite variation within and among populations of Oryza officinalis (Poaceae), an endangered wild rice from China. Mol. Ecol. 14: 4287-4297.

Gao, L.Z., S. Ge \& D.Y. Hong. 2000. Allozyme variation and population genetic structure of common wild rice Oryza rufipogon Griff. in China. Theor. Appl. Genet. 101: 494-502.

Gao, L.Z., S. Ge \& D.Y. Hong. 2002a. Allozyme variation and conservation genetics of common wild rice (Oryza rufipogon Griff.) in Yunnan, China. Euphytica 124: 273-281.

Gao, L.Z., B.A. Schaal, C.H. Zhang, J.Z. Jia \& Y.S. Dong. 2002b. Assessment of population genetic structure in common wild rice Oryza rufipogon Griff. using microsatellite and allozyme markers. Theor. Appl. Genet. 106: 173-180.

Gao, L.Z. 2004. Population structure and conservation genetics of wild rice Oryza rufipogon (Poaceae): a region-wide perspective from microsatellite variation. Mol. Ecol. 13: 1009-1024.

Gao, L.Z., C.H. Zhang, D.Y. Li, D.J. Pan, J.Z. Jia \& Y.S. Dong. 2006. Genetic diversity within Oryza rufipogon germplasms preserved in Chinese field gene banks of wild rice as revealed by microsatellite markers. Biol. Conservat. 15: 4059-4077.

Ge, S., G.C.X. Oliveira, B.A. Schaal, L.Z. Gao \& D.Y. Hong. 1999. RAPD variation within and between natural populations of the wild rice Oryza rufipogon from China and Brazil. Heredity 82: 638-644.

Glaszmann, J.C. 1988. Geographical pattern of variation among Asian native rice cultivars (Oryza sativa L.) based on 15 isozyme loci. Genome 30: 782-792.

Goldstein, D.B. \& C. Schlöterrer. 2000. Microsatellites: evolution and applications. Oxford University, New York, USA.

Goodman, S.J. 1997. $\mathrm{R}_{\mathrm{ST}}$ Calc: a collection of computer program for calculating estimates of genetic differentiation from microsatellite and determining their significance. Mol. Ecol. 6: 881-885.

Goudet, J. 1995. FSTAT (Version 1.2): A computer program to calculate F-statistics. J. Hered. 86: 485-486.

Hames, D.B. 1996. One-dimensional polyacrylamide gel electrophoresis, p. 1-139. In D.B. Hames \& D. Rickwood (eds.). Gel electrophoresis of proteins: a practical approach. Oxford, New York, USA.

Hoisington, D., M. Khairallah \& D. Gonzalez-de-Leon. 1994. Laboratory Protocols: CYMMYT Applied Molecular Genetics Laboratory. CYMMYT, El Batan, Texcoco, Mexico.

Karasawa, M.M.G., R. Vencovsky, C.M. Silva, M.I. Zucchi, G.C.X. Oliveira \& E.A. Veasey. 2007a. Genetic structure of Brazilian wild rice (Oryza glumaepatula Steud., Poaceae) populations analyzed 
using microsatellite markers. Genet. Mol. Biol. 30: 400-410.

Karasawa, M.M.G., R. Vencovsky, C.M. Silva, M.I. Zucchi, G.C.X. Oliveira \& E.A. Veasey. 2007b. Mating system of Brazilian Oryza glumaepatula populations studied with microsatellite markers. Ann. Bot. 99: 245-253.

Lewis, P.O. \& D. Zaykin. 2000. Genetic Data Analysis: computer program for the analysis of allelic data. Version 1.0 (d15). Department of Ecology and Evolutionary Biology, University of Connecticut, Connecticut, United States of America. (Downloaded: December 20, 2000, http://hydrodictyon. eeb.uconn. edu/people/plewis/software.php).

Lewontin, R.C. \& J. Hubby. 1966. A molecular approach to the study of genetic heterozygosity in natural populations. II. Amounts of variation and degree of heterozygosity in natural populations of Drosophyla pseudoobscura. Genetics 54: 595-609.

Li, Y.C., A.B. Korol, T. Fahima \& E. Nevo. 2004. Microsatellites within genes: structure, function, and evolution. Mol. Biol. Evol. 21: 991-1007.

Lowe, A., S. Harris \& P. Ashton. 2007. Ecological genetics: design, analysis and application. Blackwell, Oxford, United Kingdom.

Mantel, N. 1967. The detection of disease clustering and a generalized regression approach. Cancer Res. 27: 209-220.

Miller, M. 1997. Tools for population genetic analyses (TFPGA) 1.3: A windows program for analysis of allozyme and molecular population genetic data. Northern Arizona University, Flagstaff, Arizona, United States of America. (Downloaded: April 13, 2000, www.public.asu.edu).

Morishima, H. 1994. Background information about Oryza species in tropical America, p. 4-5. In H. Morishima \& P.S. Martins (eds.). Investigations of plant genetic resources in the Amazon basin with the emphasis on the genus Oryza: Report of 1992/93 Amazon Project. The Monbusho International Scientific Research Program, Mishima, Japan and Research Support Foundation of the State of São Paulo, São Paulo, Brazil.

Morishima, H. \& P. Barbier. 1990. Mating system and genetic structure of natural populations in wild rice Oryza rufipogon. Plant Species Biol. 5: 31-39.

Murphy, R.W., J.W. Sites, D.G. Buth \& C.H.H. Haufler. 1990. Proteins I: Isozyme electrophoresis. In D.M. Hillis \& C. Moritz (eds.). Molecular Systematics. Part II. Sinauer, Sunderland, Massachusetts, USA.

Nei, M. 1973. Analysis of gene diversity in subdivided populations. Proc. Natl. Acad. Sci. USA. 70: 3321-3323.
Nei, M. 1978. Estimation of average heterozygosity and genetic distance from a small number of individuals. Genetics 89: 583-590.

Oliveira, G.C.X. 1993. Padrões de variação fenotípica $e$ ecologia de Oryzae selvagens da Amazônia. M.S. Dissertation, Escola Superior de Agricultura "Luiz de Queiroz”, Universidade de São Paulo, Piracicaba, Brazil.

Oliveira, G.C.X. 1994. Geographic distribution of wild Oryza species in Brazil, p. 10-15. In H. Morishima \& P.S. Martins (eds.). Investigations of plant genetic resources in the Amazon basin with emphasis on the genus Oryza. Report of 1992/93 Amazon Project, The Monbusho International Scientific Research Program, Japan, and FAPESP, Brazil.

Panaud, O., X. Chen \& S.R. McCouch. 1995. Frequency of microsatellite sequences in rice (Oryza sativa L.). Genome 38: 1170-1176.

Paetkau, D., W. Calvert, I. Stirling \& C. Strobeck. 1995. Microsatellite analysis of population structure in Canadian polar bears. Mol. Ecol. 4: 347-354.

Rohlf, J. 1992. NTSYS-pc: numerical taxonomy and multivariate analysis system. Version 1.70 (software). Applied Biostatistics, New York, USA.

Schlötterer, C. 2004. The evolution of molecular markers - just a matter of fashion? Nat. Rev. Genet. 5: 63-69.

Silva, C.M., M.M.G. Karasawa, R. Vencovsky \& E.A. Veasey. 2007. Elevada diversidade genética interpopulacional em Oryza glumaepatula Steud. (Poaceae) avaliada com microssatélites. Biota Neotrop. 7: 1-7.

Slatkin, M. 1987. Gene flow and the geographic structure of natural populations. Science 236: 787-792.

Slatkin, M. 1995. Measure of population subdivision based on microsatellite allele frequencies. Genetics 139: 457-462.

Sun, G.L., O. Díaz, B. Solomon \& R. von Bothmer. 2001. Genetic diversity and structure in a natural Elymus caninus population from Denmark based on microsatellite and isozyme analyses. Plant. Syst. Evol. 227: 235-244.

Vaughan, D.A., H. Morishima \& K. Kadowaki. 2003. Diversity in the Oryza genus. Curr. Opin. Plant Biol. 6: 139-146.

Vaz, A.R.C., T.C.O. Borba, C. Brondani, P.H.N. Rangel, G.S.O. Camargo, M.P.C. Telles, J.A.F. Diniz Filho \& R.F.V. Brondani. 2009. Genetic analysis of a local population of Oryza glumaepatula using SSR markers: implications for management and conservation programs. Genetica 137: 221-231.

Veasey, E.A., D.C. Cardin, R.M. Silva, E.A. Bressan \& R. Vencovsky. 2008. Assessing the genetic structure of Oryza glumaepatula populations with isozyme markers. Braz. Arch. Biol. Technol. 51: 873-882. 
Vigouroux, Y., J.C. Glaubitz, Y. Matsuoka, M.M. Goodman, G.J. Sánchez \& J. Doebley. 2008. Population structure and genetic diversity of new world maize races assessed by DNA microsatellites. Am. J. Bot. 95: 1240-1253.

Wang, M.X., H.L. Zhang, D.L. Zhang, Y.W. Qi, Z.L. Fan, D.Y. Li, D.J. Pan, Y.S. Cao, Z.E. Qiu, P. Yu, Q.W Yang, X.K. Wang \& Z.C. Li. 2008. Genetic structure of Oryza rufipogon Griff. in China. Heredity 101: 527-535.

Weir, B.S. 1996. Genetic data analysis II: Methods for discrete population genetic data. Sinauer, Sunderland, USA.
Xu, X., B.R. Lu, Y.H. Chen, M. Xu, J. Rong, P. Ye, J. Chen \& Z. Song. 2006. Inferring population history from fine-scale spatial genetic analysis in Oryza rufipogon (Poaceae). Mol. Ecol. 15: 1535-1544.

Yoshimura, A., H.N. Sobrizal, T. Kurakazu, P.L. Sanchez, K. Doi, Y. Yamagata \& H. Yasui. 2010. Introgression lines of rice (Oryza sativa L.) carrying a donor genome from the wild. Breed. Sci. 60: 597-603.

Zhou, H.F., W.X. Zhong \& S. Ge. 2003. Microsatellite analysis of genetic diversity and population genetic structure of a wild rice (Oryza rufipogon Griff.) in China. Theor. Appl. Genet. 107: 332-339. 